\title{
GASTO PÚBLICO E DESIGUALDADE SOCIAL $O$ orçamento do governo federal brasileiro entre 1995 e 2016
}

\section{Ursula Dias Peres}

(D) https://orcid.org/0000-0002-7853-0576

\section{Fábio Pereira dos Santos}

\author{
(D) https://orcid.org/0000-0003-3302-0019 \\ (1) Universidade de São Paulo (USP), Centro de Estudos da Metrópole (CEM), São Paulo - SP, Brasil. - E-mail: uperes@usp.br \\ (2) Câmara Municipal de São Paulo (CMSP), São Paulo - SP, Brasil. - E-mail: fabiopereira1@gmail.com
}

DOI: $10.1590 / 3510307 / 2020$

\section{Introdução}

A análise do orçamento público é fundamental para a compreensão das escolhas dos governos e da trajetória das políticas públicas, tanto porque revela quanto se gasta como também os mecanismos pelos quais tais gastos são financiados.

Três premissas orientam a análise que apresentamos neste artigo. A primeira é o fato de que o orçamento público é objeto de conflitos distributivos entre distintos interesses. A segunda aponta que essa disputa não ocorre no vazio - diferentemente, é afetada por regras de formatação orçamentária que expressam motivaçóes. Além disso, escolhas prévias criam constrangimentos institucionais, reduzindo a margem de escolha dos governos presentes. A despeito disso, preferências partidárias e programáticas podem ser

Artigo recebido em: 08/03/2019

Aprovado em: 16/10/2019 detectadas nas mudanças introduzidas na alocação orçamentária.

A trajetória do orçamento público brasileiro no regime democrático contemporâneo foi afetada por dimensões que não operam de modo convergente. Ao contrário, o orçamento público é resultado de dinâmicas que funcionam contraditoriamente. A primeira delas diz respeito à centralização versus descentralização dos recursos públicos. A trajetória do orçamento público brasileiro também foi afetada pela permanente disputa pelo fundo público versus a vinculação constitucional/legal de recursos a determinadas despesas. Em terceiro lugar, açôes de maior transparência das informaçóes e accountability sobre os orçamentos foram acompanhadas por aumento da complexidade orçamentária. Por fim, a ampliação do gasto social - que produziu a redução das desigualdades sociais - conviveu com a regressividade da arrecadação tributária. 
A primeira dimensão diz respeito a uma das bases fundantes da Constituição Federal de 1988 (CF), que é a autonomia dos entes federativos e um pacto fiscal coerente com tal autonomia, capaz de reequilibrar um federalismo abalado pela ditadura militar. A CF previu uma redivisão de recursos tributários para estados e especialmente municípios, aumentando os recursos locais.

Por outro lado, durante os anos 1990, a prerrogativa da União para cobrança de contribuiçóes tornou possível recentralizar recursos, aumentando a carga tributária não compartilhada com os demais entes da federação. Também houve um processo, mais lento e incremental, de descentralização e municipalização de despesas e de implementação de políticas públicas, acompanhado de centralização da autoridade sobre o desenho dessas políticas no nível federal, por meio de açôes de controle e de indução através de repasse de recursos federais (Almeida, 2005, p. 34; Arretche, 2005, p. 78-79).

Em relação à segunda dimensão, a forte pressão desde o final dos anos 1970 e ao longo dos anos 1980 para a democratização da discussão sobre alocação dos recursos públicos resultou no aumento de processos e práticas participativas e, consequentemente, na ampliação de grupos de interesses, movimentos e partidos na negociação orçamentária.

A CF vinculou parcelas de recursos e estabeleceu regras de gasto em áreas como educação e saúde. A alocação do fundo público foi se cristalizando em normas constitucionais e infraconstitucionais, reduzindo o espaço de conflito e negociação de recursos entre diferentes setores de políticas públicas. Se nos anos 1990 e início dos anos 2000 ampliaram-se o número de instâncias participativas, como conselhos de políticas setoriais (saúde, educação, crianças e adolescentes e assistência social, entre outros), e os orçamentos participativos, em que se discutiriam a despesa global e a receita, nos últimos anos essas arenas de discussão de orçamento e conflito distributivo foram se tornando muitas vezes rotineiras e burocráticas (Peres e Mattos, 2017).

Essa dinâmica de transformaçôes institucionais, que modifica também os atores, ilustra o que Pierson (1993) chama de policy feedbacks, situações em que as instituições passam a ser "variáveis independentes" que resultam em mudanças nos atores políticos e em fontes de sua própria resiliência e durabilidade com a passagem do tempo. As vinculaçóes orçamentárias podem ser entendidas, nesta chave interpretativa, como instituições que, "uma vez adotadas, reestruturam o processo político subsequente” (Skocpol, 1992, p. 57-58).

A terceira dimensão, com o estabelecimento de regras para receitas e despesas públicas nas três esferas da federação, trouxe ganho indiscutível em transparência e accountability mas, por outro lado, aumentou a complexidade dos orçamentos públicos. Essa complexidade mantém distância de boa parte da sociedade sobre o que é e como funciona a alocação de recursos públicos. Os ganhos de transparência e accountability não foram suficientes para garantir e ampliar a apropriação social sobre essa temática (Afonso, 2016; Pederiva, 2018, p. 301).

A quarta dimensão é talvez a mais importante para explicar a trajetória das finanças públicas brasileiras. A busca, nas últimas décadas, pela redução das desigualdades sociais por meio de políticas públicas inclusivas ocorreu em conjunto com a sobrevivência de instituiçôes e políticas de concentração de renda e manutenção de privilégios.

Um exemplo claro do processo de redução da desigualdade de renda pode ser visto nas políticas de valorização do salário mínimo, com reajustes reais de valor além da correção monetária, e de transferência de renda (previdência social, que passou a incluir uma parte marginalizada da população, excluída até 1988; Benefício de Prestação Continuada - BPC e Bolsa Família, principalmente). Barros, Henriques e Mendonça (2000), que usaram dados da Pesquisa Nacional por amostra de domicílios (PNAD) para evidenciar a persistência da pobreza (com leve redução) até o final dos anos 1990, mostraram que o principal fator que explicava a pobreza era a desigualdade de renda. Barros et al. (2006) concluíram que as mudanças no mercado de trabalho e na rede de proteçáo social causaram queda da desigualdade no início dos anos 2000.

Ao mesmo tempo em que a rede de proteção social foi ampliada no período 1995-2016, foi mantida a política tributária regressiva calcada em impostos indiretos e sobrepostos, junto com uma tímida e 
regressiva taxação da renda e do patrimônio no país, contraditória com a redução de desigualdades, como argumentaram vários trabalhos que analisaram diferentes aspectos e subperíodos (Fagnani, 2019, p. 19; Fandiño e Kerstenetzky, 2019, p. 307; Silveira, 2012, p. 65).

Morgan (2017) mostrou, usando dados das Contas Nacionais, do Imposto de Renda Pessoa Física (IRPF) e da PNAD, que a redução das desigualdades de renda provenientes do trabalho e das transferências de renda resultou em aumento do percentual da renda apropriado pelos $50 \%$ mais pobres da populaçâo brasileira, que capturaram $22 \%$ do aumento da renda no período 2001-2015, ao mesmo tempo em que a concentração dos recursos de capital resultou em aumento da participação dos $10 \%$ mais ricos, capturando $61 \%$ do aumento de renda no período. Gobetti e Orair (2016) argumentam que a regressividade da tributação sobre a renda das pessoas físicas no Brasil não apenas se manteve como foi acentuada ao longo das últimas décadas, com aumento das isençôes e diminuição das alíquotas efetivas que incidem sobre a renda dos mais ricos. Ou seja, ao longo das últimas décadas, a política orçamentária da União, por meio de decisões tributárias e alocativas de despesas, permitiu tanto a ampliação de gastos sociais, beneficiando a população menos favorecida, como a concentraçáo de renda no topo da pirâmide.

Com base neste argumento e nas quatro dimensōes apresentadas, analisamos os gastos orçamentários federais e suas consequências para a redução da desigualdade do país. Analogamente ao trabalho de Arretche (2018), o foco no orçamento permite olhar tanto para a reduçáo da desigualdade medida pela renda monetária, quando se analisam os gastos federais em previdência e assistência social (transferências de renda), como para a desigualdade em sua dimensáo do acesso a serviços públicos, quando a análise recai sobre os gastos com saúde e educação. Outros agrupamentos de despesas orçamentárias - pagamento de juros, subsídios e subvençôes ao setor privado, despesas de pessoal - são objeto de análise náo apenas porque causam impactos relevantes sobre a desigualdade, mas também porque influenciam decisivamente a possibilidade de aplicação de recursos nas áreas sociais. As receitas orçamentárias federais são brevemente tratadas, tanto em suas características redistributivas como em suas interaçóes com os demais entes da federação.

Ressaltamos que não pretendemos esgotar neste trabalho a discussão sobre o financiamento das diferentes políticas de responsabilidade da União. Nosso foco são as contradiçôes entre a arrecadaçáo tributária e os principais gastos federais no que diz respeito à sua contribuiçãao para a redução ou não da desigualdade. Essas limitaçóes destacam também a existência de uma agenda necessária de debate acadêmico a ser aprofundada em cada área de gastos e no plano da arrecadação federal.

O presente artigo está organizado em três seçóes, além desta introdução. A seção 1 apresenta uma breve trajetória sobre as mudanças de regras orçamentárias implementadas nas últimas décadas. Na seção 2 tratamos brevemente da composiçáo da estrutura de receitas da Uniâo, evidenciando algumas características da política tributária nacional. Na seção 3 é analisada a evolução do financiamento das principais despesas e áreas de gasto da União. Por fim, as quatro dimensôes expostas são retomadas e analisadas à luz dos dados apresentados e discutidos, incluindo brevemente a crise de financiamento ocorrida no país a partir de 2014 e as consequências da Emenda Constitucional 95/2016, que estabelece como teto das despesas primárias federais pelos próximos 20 anos o valor real observado no ano de 2016.

\section{Trajetória normativa do orçamento público no Brasil}

A Lei 4.320/1964 padronizou o orçamento brasileiro e criou condiçôes favoráveis para a implementação do orçamento-programa ${ }^{1}$ no Brasil. Este modelo, porém, teve reflexos muito mais formalistas do que de estratégia de decisão alocativa de recursos entre os diferentes programas orçamentários. Como analisado por Wildavsky (1969) e corroborado, para o caso brasileiro, por Piscitelli (1988) e Brasil (1993), o orçamento-programa brasileiro era uma ficçáo.

No início da implementação do orçamento-programa no Brasil o país estava sob uma ditadura militar. O boom econômico do final da década de 1960 a meados dos anos 1970, com aumento expressivo 
dos gastos estatais, conviveu com a desestruturação das finanças públicas, com enorme parcela de gastos realizados à margem das leis orçamentárias, além de elevada inflação.

A CF de 1988 instituiu um sistema de planejamento e orçamento composto pelo Plano Plurianual (PPA), a Lei de Diretrizes Orçamentárias (LDO) e a Lei Orçamentária Anual (LOA). O PPA tem uma finalidade estratégica e de médio prazo, e a LOA deve operacionalizar as metas do PPA. Já a LDO é uma ponte entre as metas do PPA e as ações da LOA e, após a aprovação da Lei de Responsabilidade Fiscal (LRF), define as metas de resultado fiscal a serem alcançadas.

A Constituição ampliou tanto o poder do Legislativo na definição do orçamento como a obrigatoriedade de destinação de recursos para algumas áreas de políticas públicas, como a educação (Castro, 2011) e posteriormente saúde (Faveret, 2003; Viana e Machado, 2008), estabelecendo vinculaçóes de receitas de impostos federais, estaduais e municipais. Os principais marcos dessa vinculação foram estabelecidos no artigo 212 da CF (aumentou a vinculação de 13\% para $18 \%$ da receita de impostos da Uniâo e manteve a destinação de $25 \%$ dos impostos e transferências estaduais e municipais para a educação) e na Emenda Constitucional (EC) no 29/2000 (que determinou a aplicação mínima de $15 \%$ das receitas de impostos e transferências municipais e $12 \%$ das mesmas receitas estaduais para açôes e serviços de saúde e, para a União, do valor mínimo igual ao orçamento do ano anterior corrigido pela variação do PIB nominal) e EC 86/2015, alterada pela EC 95/2016, que determinou para a União o mínimo de $15 \%$ da Receita Corrente Líquida (RCL) destinado a ações e serviços de saúde.

Até meados dos anos 1990, o país sofreu um processo inflacionário que teve importantes consequências sobre o orçamento público (Guardia, 1993). A convivência duradoura da administração pública com a inflação levou à indexação das receitas públicas e ao descontrole nas despesas. A inflaçáo permitia balancear o orçamento conforme a necessidade do Poder Executivo, controlando o conflito entre os vários atores em um processo com baixa accountability (Peres, 1999).

No cenário internacional, os anos 1990 foram de ajuste e reforma orçamentária em diversos países.
Pressionado pela instabilidade monetária e por elevado endividamento externo, o governo brasileiro buscou se adequar aos novos paradigmas fiscais internacionais, voltados principalmente à redução da participação do Estado na economia, ao controle do endividamento e à solvência dos orçamentos públicos. O Plano Real, implementado a partir de 1993/1994 pelo então ministro da Fazenda/Economia e depois presidente da República, Fernando Henrique Cardoso, foi exitoso em reduzir a inflação, mas a estratégia adotada para isso elevou o endividamento público e o desequilíbrio do setor externo da economia (Santos, 2000; Batista Jr., 2002).

Depois de uma primeira fase (1994-1998) em que o combate à inflação esteve concentrado na estratégia de âncora cambial e juros reais elevados, o desequilíbrio no setor externo, que enfrentou sucessivas crises (México 1994, Ásia 1997, Rússia 1998), obrigou o governo a desvalorizar o câmbio no início de 1999 . A partir desse momento, e no quadro de um acordo com o Fundo Monetário Internacional, a ênfase se deslocou para o ajuste fiscal. As dívidas dos entes subnacionais foram federalizadas (começando em 1997) e a União passou a decidir sobre o endividamento deles. Foram adotadas as metas de superávit primário, regras de controle sobre o déficit e a dívida de estados e municípios, e limites para a despesa de pessoal. Essas medidas foram posteriormente consolidadas na LRF.

Esse ajuste dos anos 1990, iniciado com o Plano Real e consolidado na LRF em 2000, expressou uma orientação dos governos Fernando Henrique Cardoso (1995-1998 e 1999-2002) e definiu um novo equilíbrio político na federação, com concentração de poder na União. Além da LRF, o controle do governo federal sobre as finanças subnacionais passou por medidas como a Lei Kandir (1996), aprovaçôes sucessivas do Fundo Social de Emergência/Desvinculação de Receitas da União e várias outras medidas de controle de gastos (Arretche, 2009, p. 385-392).

Alterações trazidas pela LRF resultaram em ganhos de accountability para o orçamento, especialmente com a obrigatoriedade de inclusão na LDO do anexo de metas fiscais, abrangendo a situação atuarial dos regimes de previdência, e do anexo de riscos fiscais. Os ministérios da Fazenda e do Planejamento produziram 
alteraçôes contábeis e criaram a classificação de receitas e despesas por fonte, possibilitando maior controle da União sobre as transferências e os convênios federais com os municípios. A consequência foi uma redução do arbítrio do gestor local sobre o uso dos recursos. ${ }^{2}$

O governo Lula, iniciado em 2003, deu continuidade à política econômica do governo anterior, mas sinalizou uma mudança importante nas políticas de redistribuiçâo de renda ${ }^{3}$ com a criação do Bolsa Família (Silva, 2007) e, no final de seu primeiro mandato, com a instituição de uma regra de aumento real do salário mínimo, em acordo com a variaçáo real do PIB de dois anos atrás. Brito (2015, p. 105) mostrou que essa política de valorizaçáo do salário mínimo respondeu por $72,4 \%$ da redução da desigualdade do rendimento domiciliar per capita observado entre 1995 e 2013, por meio dos canais da previdência $(37,7 \%)$, do mercado de trabalho $(26,3 \%)$ e do BPC $(8,4 \%)$.

Em 2006, o governo federal anunciou um aumento de investimentos em infraestrutura e criou o Programa de Aceleração do Crescimento (PAC), com recursos federais e execução em parte a cargo de estados e municípios. A participação dos entes subnacionais na programação do PAC requer contrapartidas, aprovação prévia de projetos, liberação de recursos em funçáo da execução das obras, entre outras regras, o que mantém na Uniáo o poder decisório e o controle sobre a utilização descentralizada dos recursos.

Esse processo de centralização versus descentralização de políticas não se deu de forma linear e análoga entre os diferentes setores de políticas públicas do país. Analisando os três sistemas mais robustos e cujas despesas serão apresentadas na seção 3 , educação, saúde e assistência social tiveram processos distintos de organização.

$\mathrm{O}$ processo de descentralização da execução e de centralização das decisōes sobre a distribuição de recursos na educação teve início já na CF de 1988 e foi aprofundado na década de 1990. A criaçáo do Fundef (Fundo de Manutenção e Desenvolvimento do Ensino Fundamental e de Valorização do Magistério) e do Fundeb (Fundo de Manutençáo e Desenvolvimento da Educação Básica e de Valorização dos Profissionais da Educaçáo) implicou uma organização diferente dos recursos próprios dos entes subnacionais e permitiu enfrentar problemas de longa data, como a escassez de vagas do ensino fundamental, que foi universalizado (Segatto e Abrucio, 2016). Contudo, restringiu os tipos de despesas em manutenção e desenvolvimento do ensino - MDE a serem realizados pelos municípios (Farenzena, 2006).

No caso da saúde, apesar da estruturação ter sido distinta, pois o financiamento foi paulatinamente pesando mais sobre os municípios, os recursos da Uniâo também têm sido utilizados para induzir uma programação padronizada entre os entes subnacionais, pelo menos até 2016 (Jaccoud e Vieira, 2018).

$\mathrm{Na}$ assistência social, a maior parte dos recursos sequer passa pela execuçáo orçamentária dos entes subnacionais, sendo executada diretamente pela União. Os municípios atuam no cadastro de potenciais beneficiários de políticas sociais, mas não participam da operacionalização do BPC, por exemplo, a cargo do INSS. O volume de recursos da União para outros programas de assistência social é muito pequeno, representando menos de $10 \%$ dos gastos nessa área nas capitais em 2016 (Brasil, 2016).

\section{Estrutura das receitas da Uniáo}

Além de definir a base para estabelecimento de novos tributos, a CF de 1988 determinou competências e a partilha tributária entre os entes federados. O financiamento federal das políticas públicas passou a contemplar parcialmente demandas de grupos que ansiavam por maior participação e espaço no financiamento público, a exemplo do aumento da vinculação de recursos para a educação, da incorporação ao orçamento do BPC, da previdência rural e do crédito subsidiado à agricultura familiar ao longo da década de 1990.

Para além das demandas sociais que pressionavam o orçamento federal nos anos 1990, a instabilidade monetária e o endividamento externo e interno estimulavam medidas de ajuste fiscal. $\mathrm{O}$ primeiro governo FHC (1995-1998) instituiu a Desvinculação de Receitas da Uniâo (DRU), criou contribuiçōes federais e elevou a receita de contribuiçôes já existentes (Contribuição para o Financiamento da Seguridade Social - Cofins, Coontribuição Social sobre o Lucro Líquido - CSLL, Programa de Integração 
Social - PIS, entre outras), de forma a compensar as perdas tributárias constitucionais, elevar a arrecadação federal e interromper a trajetória de queda da receita disponível observada desde os anos 1980 (Afonso, 2004, p. 10).

Do ponto de vista das receitas, como já afirmado, parcela importante dos recursos públicos foi descentralizada a partir da CF de 1988 e transferida aos entes subnacionais. O gráfico 1 mostra que, de 1980 a 1990, a participação do governo central na receita disponível diminuiu de $68,2 \%$ para $58,9 \%$, enquanto a dos estados aumentou de $23,3 \%$ para $27,6 \%$, e a dos municípios de $8,6 \%$ para $13,5 \%$. Nos anos 1990, várias alteraçóes legislativas contribuíram para interromper a queda na participação da União na receita pública disponível, levando a uma relativa estabilização, entre 2000 e 2016, em torno de 55\% para a União, 25\% para os estados e cerca de 20\% para os municípios (Afonso, Lukic e Castro, 2018).

Essa trajetória de descentralização, seguida de estabilização na disponibilidade de receitas, produziu aumento da participação dos entes subnacionais, sobretudo os municípios, no financiamento de políticas de educação básica e saúde, e a elevação dos gastos federais em previdência social, assistência social e subsídios ao setor privado, conforme detalhado em seções posteriores deste trabalho.

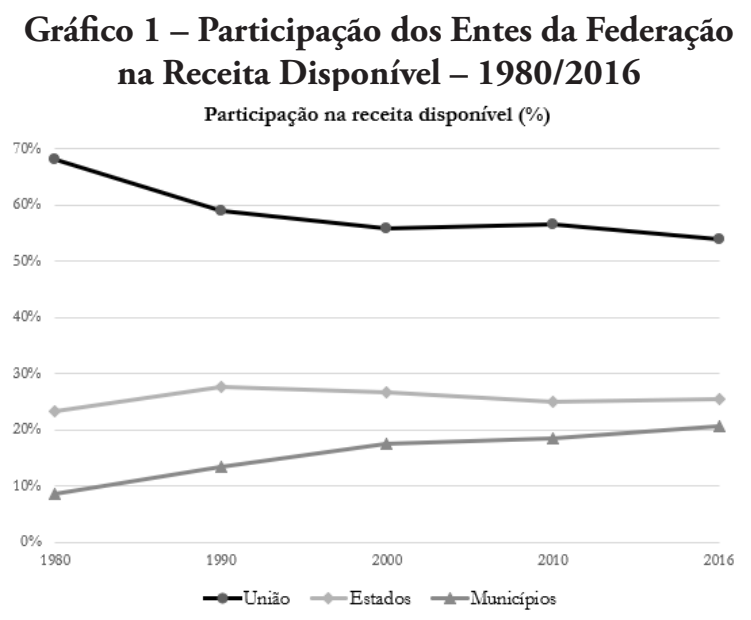

Fonte: Elaboração própria com base em dados da STN, RFB, CEF e IBGE, extraídos de Afonso, Lukic e Castro (2018)
Do ponto de vista social, a resultante redistributiva da política tributária foi o agravamento da desigualdade de renda e o aumento da cumulatividade do sistema tributário sobre a produçáo e o consumo, já tributados por outros impostos (Granado e Peres, 2010).

As opçóes adotadas pelo governo federal desde meados dos anos 1990, sobretudo nos governos FHC, para cobrança do Imposto sobre a Renda da Pessoa Física - IRPF, especialmente a isenção de pagamento de IRPF sobre os ganhos com lucros e dividendos, produziram alíquotas efetivas significativamente menores para os recebedores deste tipo de rendimento quando comparados a não recebedores de lucros e dividendos na mesma faixa de renda (Fernandes, Campolina e Silveira, 2019, p. 27-28).

Essa injustiça tributária redundou em "uma situação paradoxal em que as alíquotas médias do IRPF passam a cair no topo da distribuição e quebram sua escada de progressividade" (Gobetti e Orair, 2016, p. 09). Um exemplo do resultado desta opção está na diminuição das alíquotas efetivas do IRPF para todas as faixas de renda acima de 20 salários mínimos entre os anos de 2007 e 2016. Enquanto a alíquota efetiva cresceu de $3,1 \%$ para $4,51 \%$ para rendas mensais até 20 salários mínimos, no caso de rendas acima desta linha houve diminuição em todas as faixas no período em questão, e chamam a atenção a redução de 4,62 pontos percentuais na alíquota daqueles com renda entre 80 e 160 salários mínimos mensais e a redução de 4,40\% para apenas $2,53 \%$ da alíquota dos contribuintes com renda superior a 160 salários mínimos mensais.

É importante ressaltar que essa trajetória se manteve nos governos do PT. O governo Lula chegou a enviar ao Congresso Nacional uma Proposta de Emenda Constitucional (PEC 41/2003) instituindo a progressividade de alguns impostos, mas não houve acordo no Congresso para essas alteraçóes (Lazzari e Leal, 2017, p. 6).

Sem enfrentar o conflito inerente a uma reforma dos impostos sobre a renda e patrimônio, a principal fonte de aumento da arrecadação da União foram, como já citamos, as contribuiçôes, que cresceram 54 pontos percentuais a mais que o conjunto das receitas correntes e 83 pontos percentuais a mais que as receitas de impostos entre 1995 e 2016, como mostra o gráfico 2 . 


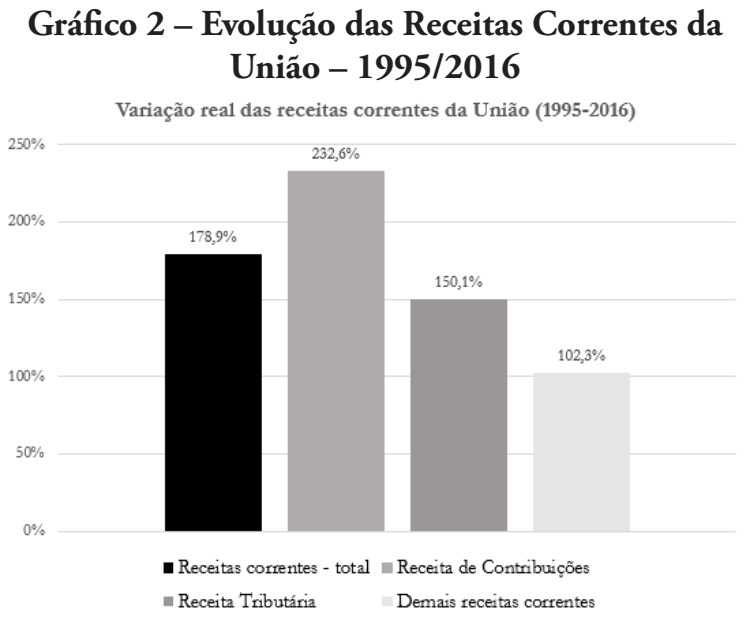

Fonte: Elaboração própria. Valores atualizados pelo IPCA. Dados do site STN

A evolução das receitas orçamentárias no período pós 1995 pode ser caracterizada, assim, pela síntese entre redução da participação da Uniâo e aumento da parcela dos municípios, deslocamento da origem das receitas federais dos impostos para as contribuiçôes e agravamento da regressividade da tributação. Essa combinação, potencializada pelas sucessivas medidas de desvinculação de receitas da União e de ampliação da carga tributária aprovadas desde a implantação do Plano Real, propiciou o aumento da participação dos municípios nos gastos públicos nacionais de políticas como saúde e educação, enquanto o orçamento federal criou espaços para elevados superávits fiscais entre 1999 e 2013 e para a ampliação dos gastos em previdência e assistência social.

Esse cenário das receitas, associado à estrutura dos gastos públicos, que será discutida na próxima seção, e à crise política nacional, levou a uma crise fiscal de grandes proporçóes em 2015 e 2016, que provavelmente terá impactos importantes sobre a capacidade de o gasto público federal incidir positivamente sobre a desigualdade social nos próximos períodos.

\section{Estrutura da despesa orçamentária da Uniáo}

Nesta seção serão analisadas as principais despesas do governo federal, agrupadas em três subseções referentes (i) às maiores áreas do gasto social - previdência social, saúde e assistência social (seguridade social) e educação; (ii) ao serviço da dívida e subsídios; (iii) à discussão da rigidez orçamentária do gasto federal, em especial dos gastos de pessoal. O objetivo é descrever a evoluçáo desses gastos e apontar os principais impactos do orçamento federal sobre a desigualdade social no período 1995-2016. É relevante, contudo, ressaltar novamente que não se pretende aqui esgotar a discussão existente na literatura sobre o financiamento de cada uma dessas áreas de políticas públicas. $\mathrm{O}$ intuito é limitado a demonstrar o espaço orçamentário dessas políticas e suas principais consequências redistributivas.

\section{Priorização de áreas sociais: previdência, saúde, educação e assistência social}

Previdência

Apesar de todas as despesas terem crescido no período de 1995 a 2016, a previdência social teve uma evolução bastante superior às demais, passando de 4,98\% do PIB em 1995 para 9,24\% em 2016 (Castro et al., 2012).

Esse crescimento está associado a características do sistema previdenciário e da população brasileira. Em primeiro lugar, a opção dos constituintes de 1988 de atrelar a remuneração básica da previdência ao salário mínimo tornou parcela importante dos benefícios independente das contribuiçóes previdenciárias realizadas (Medeiros e Souza, 2014) e permitiu valorizar aposentadorias, pensões e benefícios assistenciais vinculados ao piso, tendo em vista os ganhos reais do salário mínimo, iniciados no governo $\mathrm{FHC}$ em 1995, acelerados durante os dois mandatos de Lula (2003-2010) e mantidos até 2016. ${ }^{4}$ Por sua vez, o envelhecimento populacional, com o aumento da expectativa de vida dos mais idosos, mantém beneficiários recebendo por mais tempo recursos da previdência. Estes fatores tornaram essa função, isoladamente, o principal gasto social do governo.

Esses mecanismos permitiram atenuar a desigualdade ao beneficiarem as camadas mais pobres da população, em especial na área rural (Helfand, Rocha e Vinhais, 2009), e de forma geral os beneficiários do Regime Geral de Previdência Social (RGPS). ${ }^{5}$ 
Medeiros e Souza (2014) também mostraram que o RGPS é progressivo, com coeficiente de concentração inferior ao índice de Gini. O contrário ocorre com o Regime Próprio de Previdência Social (RPPS), de servidores públicos, para o qual encontraram coeficiente de concentração 1,5 vez superior ao índice de Gini, usando dados da POF 2008/2009.

Saúde

A regra de financiamento do SUS ficou em parte indefinida durante praticamente todo o período 1995-2016, até a aprovação da Emenda Constitucional no 86/2015, que estabeleceu uma aplicação mínima de $15 \%$ da Receita Corrente Líquida da União em saúde. ${ }^{6}$ Assim, como mostra o gráfico 3, a União reduziu sua participação de $63,8 \%$ dos gastos públicos em saúde em 1995 para menos de $43 \%$ em 2016, enquanto os municípios aumentaram seu financiamento de $17,4 \%$ para $31,6 \%$, e os estados passaram de $18,8 \%$ para $25,5 \%$ no mesmo período.

Apesar de o gasto federal em saúde ter caído como proporção do PIB ao longo dos últimos 20 anos (de 1,79\% em 1995 para 1,57\% em 2016), a trajetória da despesa pública total em saúde foi de crescimento contínuo e em ritmo mais intenso que o do gasto privado. As despesas públicas com saúde passaram de 3,1\% do PIB em 2000 para 3,9\% do PIB em 2015, enquanto os gastos privados aumentaram de 5,0\% do PIB para 5,2\% do PIB no mesmo período (Brasil, 2019). O aumento da despesa pública em saúde foi devido, principalmente, aos entes subnacionais: os estados passaram a aplicar $12 \%$ e os municípios $15 \%$ de suas receitas de impostos e transferências em saúde a partir de 2001, em razão da entrada em vigor da Emenda Constitucional no 29/2000. Nesse mesmo período, as despesas federais em saúde foram indexadas à variação do PIB nominal, partindo de um valor base, para o ano de 2000, igual ao valor empenhado no exercício de 1999, acrescido de 5\%.

\section{Educação}

O financiamento da educação no Brasil conta com vinculação constitucional de impostos nas três esferas, sendo a União ${ }^{7}$ responsável pela aplicação

\section{Gráfico 3 - Participação Relativa do Gasto Público com Açóes e Serviços Públicos de Saúde por Esfera da Federação (1995-2016)}

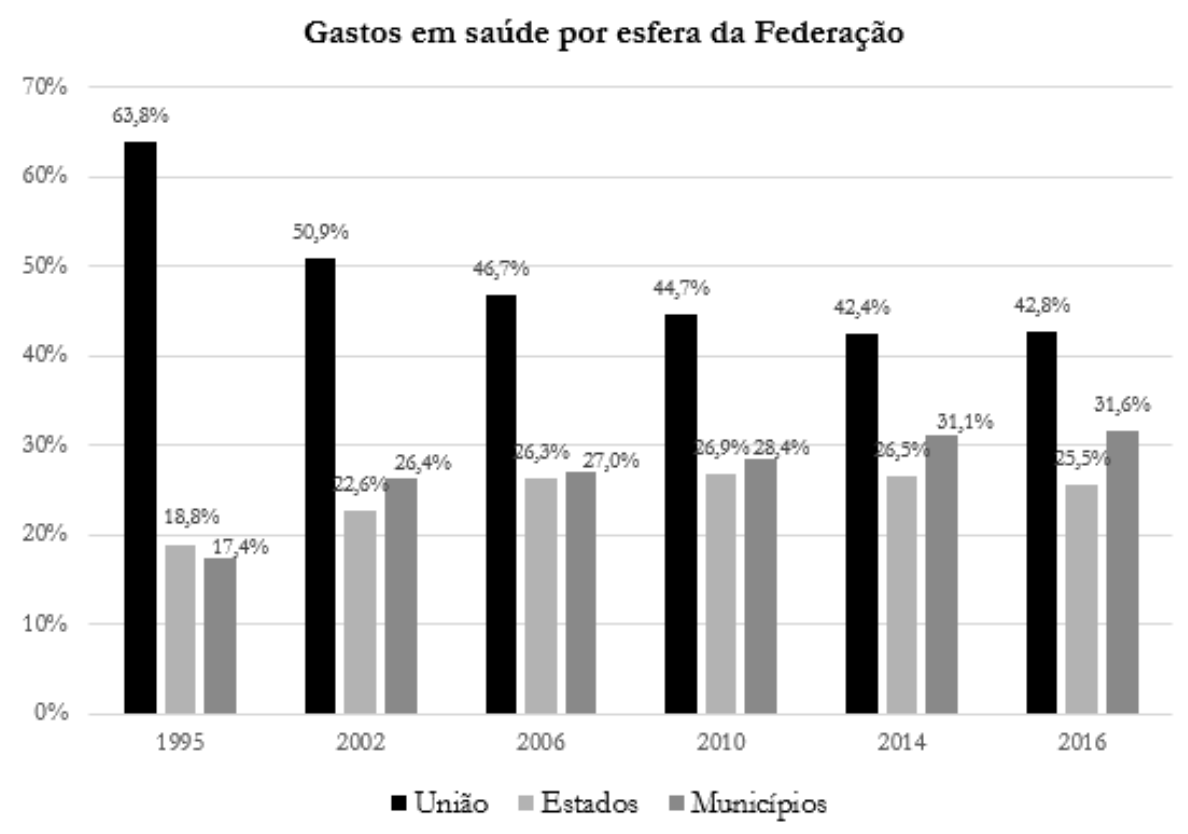

Fonte: Elaboração própria com dados de Brasil (2011), Levi (2016), Piola, Benevides e Vieira (2018), Mendes e Funcia (2016) 
de $18 \%$ de seus impostos e os estados e municípios pela aplicação de, no mínimo, $25 \%$ da receita de seus impostos na manutençáo e desenvolvimento do ensino - MDE.

Apesar da existência desse mecanismo de financiamento desde a década de 1980, os anos seguintes à promulgaçáo da $\mathrm{CF} / 1988$ foram marcados pela desigualdade educacional, com agravamento dos indicadores de analfabetismo, não universalização do ensino fundamental e indefinição do conceito de MDE (Rezende Pinto e Adriáo, 2006), com utilizaçấo dos recursos para despesas que não eram consideradas educação.

O contexto de implementação da descentralização caracterizava-se pela assimetria de informaçóes entre os entes e baixo estímulo à cooperação, aliado à inexistência de estratégia, por parte do governo federal, sobre o processo de transferência de competências (Castro, Barreto e Corbucci, 2000).

Uma definiçáo mais precisa sobre o conceito de MDE só veio a ocorrer em 1996, com a promulgação da Lei de Diretrizes e Bases da Educaçẫo Nacional (Lei 9.394/1996). A solução encontrada para enfrentar o problema de coordenação e agência se deu por meio da criação de uma nova engenharia financeira, a partir da subvinculação de recursos destinados à educação, isto é, com a criaçáo em 1996 do Fundef (Martins, 2010).

Esse mecanismo representava um fundo contábil constituído por $15 \%$ da arrecadação de impostos e transferências governamentais de estados e municípios, estruturado no âmbito de cada estado (Callegari, 2013; Gomes, 2013; Brasil, 1996b). Rodriguez (2001) ressalta que o Fundef obteve resultados consideráveis relativos ao seu objetivo inicial, qual seja, de atuar como mecanismo incentivador da universalização das matrículas de ensino fundamental. Em cerca de dois anos já se alcançava quase a totalidade desta meta, com expressivo crescimento de matrículas na rede municipal, levando a uma proporçáo de cerca de $60 \%$ da oferta municipal em face de $40 \%$ da estadual, o inverso do que se constatava até 1997. Conforme Rezende Pinto (2002) e Rodriguez (2001), a engenharia financeira construída a partir da subvinculação dos recursos do Imposto sobre Circulação de Mercadorias e Serviços (ICMS),
Fundo de Participaçáo dos Estados (FPE), Fundo de Participaçáo dos Municípios (FPM) e Imposto sobre Produtos Industrializados (IPI) explicam, em grande parte, o aumento da oferta de vagas, visto que o recebimento de transferências do Fundef aos municípios estava atrelado ao número de matrículas registradas no censo escolar. Aumentar matrículas para os municípios significava garantir ou aumentar suas receitas, e para os estados representava repassar aos municípios os encargos de administração das escolas de ensino fundamental, reduzindo suas despesas operacionais correntes e futuras (profissionais inativos).

Entretanto, por focalizar essencialmente a universalização do ensino fundamental, o Fundef produziu diminuiçáo de investimentos nas etapas de educação infantil e ensino médio (Rodriguez, 2001). Com o fim do período de vigência do Fundef, em 2006, as redes de ensino, as comunidades epistêmicas e as organizaçóes da sociedade civil se mobilizaram para ampliar o fundo, abrangendo a educação infantil e o ensino médio. A Emenda Constitucional no 53 foi aprovada em 2006, criando o Fundeb (Peres, 2007; Callegari, 2010).

O Fundeb possui estrutura de financiamento semelhante à de seu antecessor, mas prevê aumento de recursos, passando de $15 \%$ para $20 \%$ a proporção das receitas de impostos e transferências a serem retidas no fundo para o financiamento das modalidades e dos níveis da educação básica e também ampliando a participaçáo da Uniấo na complementaçáo de recursos.

A aplicação de recursos da União em educação, como porcentagem das receitas de impostos, variou expressivamente entre 1995 e 2016, sendo que entre 2000 e 2005 os gastos em MDE variaram entre 15,9\% e $17,96 \%$ da receita líquida de impostos, ficando abaixo da determinação constitucional (que é de 18\%), como mostra o gráfico 4. No entanto, a partir de 2006, a Uniāo passou a aplicar mais que o mínimo constitucional, embora entre 1997 e 2010 o valor da receita considerada estivesse reduzido pela incidência do Fundo de Estabilização Fiscal e da Desvinculação de Receitas da Uniáo - DRU. Desde 2011 a DRU deixou de afetar a área da educaçáo. De 2005 para 2006, a porcentagem das despesas federais em MDE, como parte das receitas de impostos, saltou de 17,96\% para $24 \%$, voltando a cair para valores entre $18,5 \%$ e 


\section{Gráfico 4 - Gastos Federais com Manutençáo e Desenvolvimento do Ensino (1995 a 2016) \\ Despesas federais com Manutenção e Desenvolvimento do Ensino}

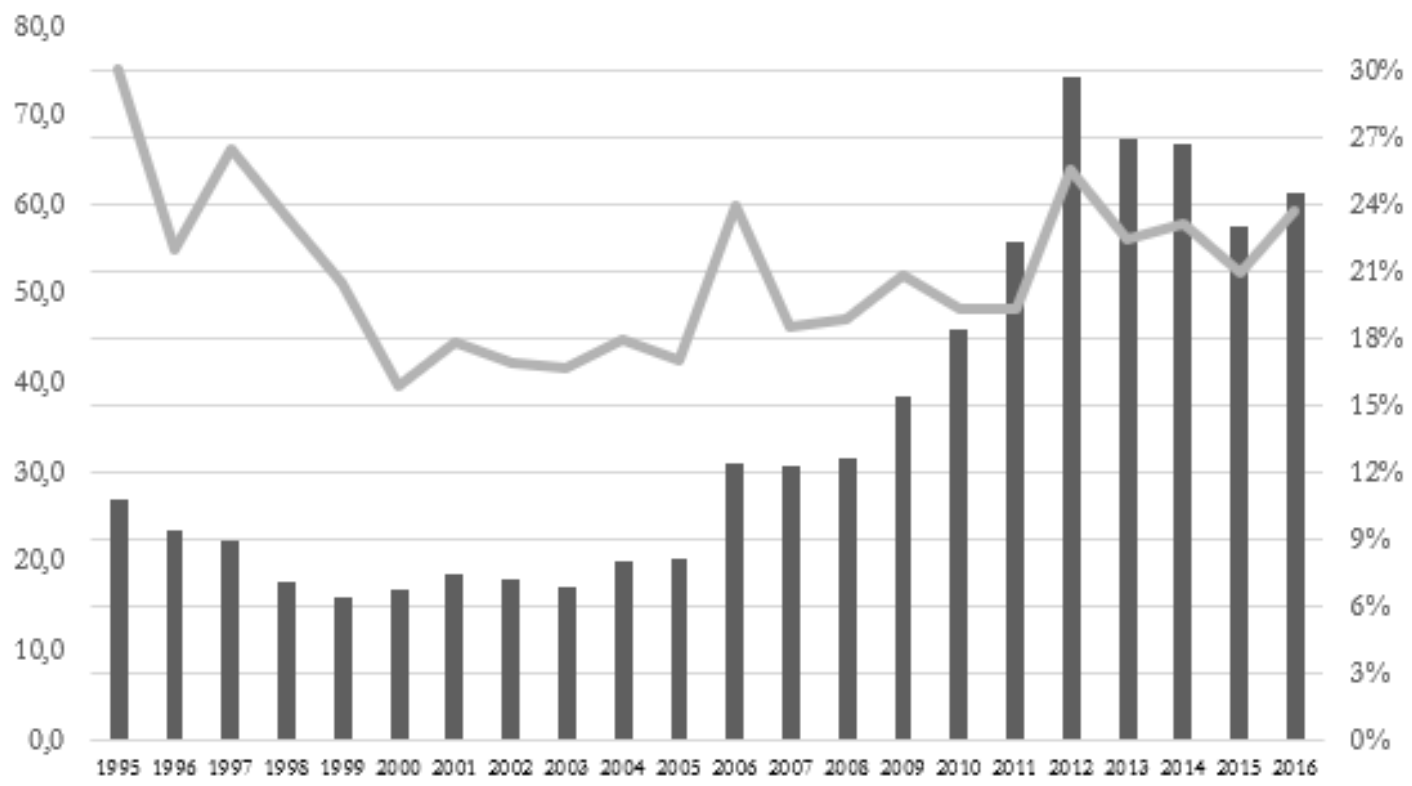

Fonte: Elaboração própria com dados do TCU (1995 a 1999) e Siconfi-STN (2000 a 2016)

$20,9 \%$ nos cinco anos seguintes, tendo novo pico de gastos em 2012, quando atingiu 25\%, diminuindo para menos de $21 \%$ em 2015 e voltando a cerca de $24 \%$ em 2016.

Do ponto de vista federativo, com a complementação da União, vários estados (na maioria das regióes Norte e Nordeste) foram contemplados com mais recursos e houve elevação dos gastos mínimos por aluno. É importante destacar que nas últimas duas décadas aumentou a aplicação de recursos públicos em educação, partindo de 4,7\% do PIB em 2000 e chegando a 6,4\% do PIB em 2012, segundo dados do Inep. Destacam-se os municípios, únicos entes federativos que aumentaram progressivamente a alocação de recursos nesta função, crescendo cerca de $0,1 \%$ anualmente de 2003 (1,8\% do PIB) até 2012 (2,6\% do PIB) (Brasil, 2014). Diferentemente, União e estados tiveram oscilaçôes durante o período - identificam-se estagnação e decréscimo dos gastos entre os anos 2000 e 2005, nos quais a União passou de $0,9 \%$ para $0,8 \%$ e os estados, de $2 \%$ para $1,8 \%$. A partir disto, estes dois entes da federação aumentaram seus investimentos na área. A União saiu do patamar, em 2005, de 0,8\% para, em 2012, atingir a marca de $1,3 \%$, enquanto os estados saíram de 1,8\% para 2,5\% no mesmo período (Brasil, 2014).

Em síntese, mesmo com a criação do Fundeb e a regra de complementação da União, a maior parte do gasto em educação tem sido realizada pelos estados e municípios, ficando a União responsável principalmente pelo ensino superior. Além disso, alguns estudos têm apontado que parte dos municípios menores, que dependem do FPM, perde recursos com o Fundeb, enquanto municípios maiores, com receitas expressivas de ICMS, obtêm ganhos líquidos com esse fundo (Limonti, Peres e Caldas, 2014).

\section{Assistência Social}

A assistência é a área de menor volume de recursos na seguridade social, mesmo com a mudança de patamar de gastos nesta função nas últimas décadas. A despesa pública em Asistência Social passou de um mínimo de 0,08\% do PIB em 1995 para 1,24\% do PIB em 2016. Novos benefícios, bem como programas e açôes dirigidos ao enfrentamento de diferentes níveis de privação, risco e vulnerabilidade, estruturaram o Sistema Único da Assistência Social - SUAS a partir 
de 2004 (Vaitsman, Andrade e Farias, 2009). O SUAS hoje congrega todos os recursos destinados à assistência social, sejam eles benefícios, serviços ou programas de transferência de renda. Dentre os benefícios garantidos a partir de 1988, destacam-se o BPC - Benefício de Prestação Continuada e o RMV - Renda Mensal Vitalícia (em extinção). O Programa Bolsa Família, que foi estruturado no início do primeiro mandato de Lula, e ampliado ao longo dos anos, teve em 2016 uma despesa de aproximadamente $\mathrm{R} \$ 27,9$ bilhóes, atendendo a 13,5 milhóes de famílias.

Tanto o BPC quanto o Bolsa Família são benefícios transferidos diretamente a indivíduos/famílias. Já os serviços para atendimento de população vulnerável ou em situação de risco dependem da atuaçáo descentralizada nos estados e nos municípios da autoridade responsável pela assistência social, cofinanciados pela União por meio de repasses fundo a fundo, com critérios pactuados de forma federativa no âmbito do SUAS. Os montantes de financiamento entre os tipos de serviços e benefícios também são bastante distintos. O gráfico 5 abaixo permite perceber isso.

A elevaçáo dos gastos em assistência social se deu de forma conflitiva. O crescimento dos programas associados ao salário mínimo, como o BPC, parece ter sido responsável por boa parte de sua ampliação, tendo sido também fundamental para a redução da desigualdade, mas atenderam apenas parcialmente ao que se buscava na proposta da Política Nacional de Assitência Social - PNAS e do SUAS. A organizaçáo e a complementariedade de benefícios, programas de transferências de renda, serviços e projetos não se deram, ficando quase restritas a benefícios e transferências.

Ao longo das últimas décadas houve um importante papel da Uniâo na definiçấo das políticas públicas de previdência, educação, saúde e assistência aqui destacadas. É importante mencionar que, apesar de ser possível perceber a centralização na definição de recursos e a descentralização executiva em todas, é necessário reconhecer distinçôes relevantes entre elas.

$\mathrm{Na}$ previdência social, a operação do RGPS é federal, mas, embora parte das regras esteja inscrita na CF, não houve ainda a definição de uma única política para os regimes próprios. A educação é talvez o melhor exemplo de área na qual a organizaçáo de um sistema descentralizado de execuçấo, com a definiçấo centralizada e padronizada de recursos, tem sido implementada desde a Constituição.

Na saúde, apesar do desenvolvimento institucional do SUS, a questão do financiamento não foi resolvida e a União tem sistematicamente aplicado recursos insuficientes, assim como vários estados. Os municípios

\section{Gráfico 5 - Gastos da União em Assistência Social (\% do PIB) - 1995/2016}

Gastos da União em Assistência Social - \% PIB

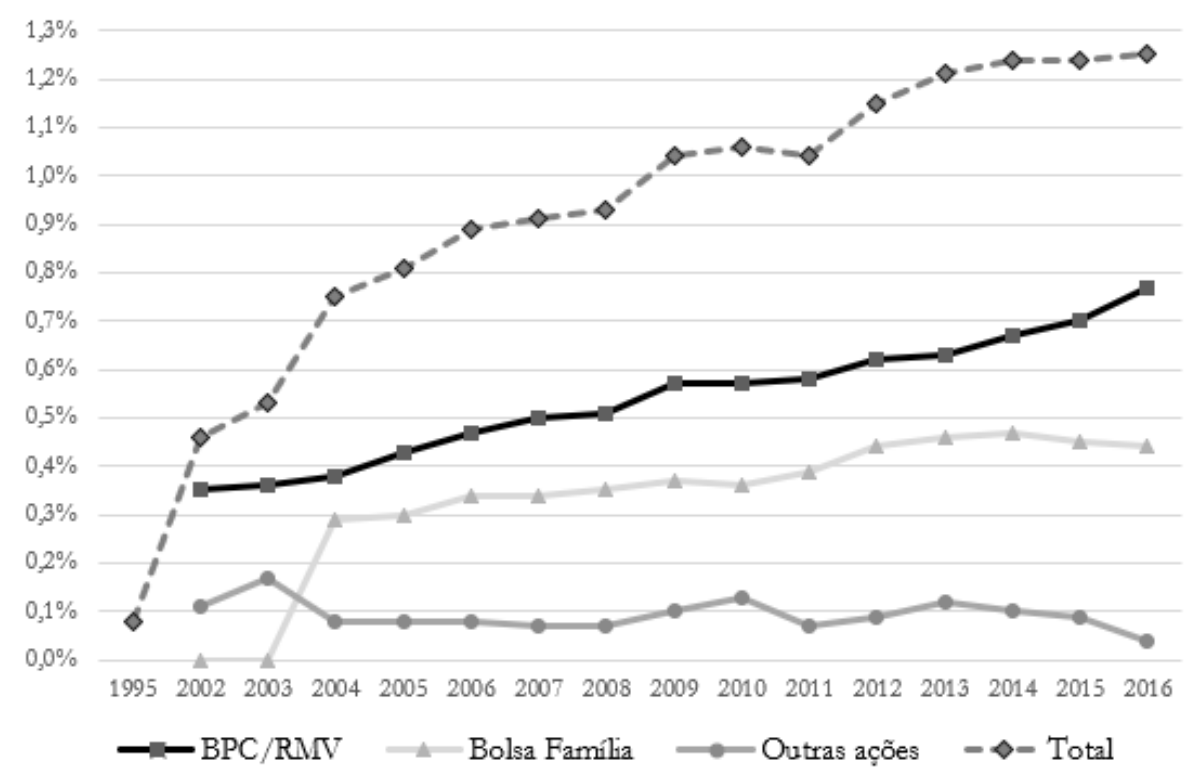

Fonte: Elaboração própria. Dados extraídos de STN e Castro et al. (2012) 
têm sofrido enorme pressão social e aplicado recursos bem acima da regra constitucional.

A assistência social tem se mostrado a menos sistematizada das três áreas sociais. Apesar da implementaçáo do SUAS ter aumentado o controle e a padronização das ações dos entes subnacionais, o peso da indução federal varia conforme a relevância das transferências do Tesouro Nacional para cada ente. Para os estados e para as capitais, os repasses para serviços cofinanciados ainda são pouco representativos em comparação com o total gasto com recursos próprios na função assintência social. ${ }^{8}$ Já para municípios de menor porte, a importância de projetos e serviços financiados pelo FNAS, no âmbito do SUAS, é bem maior (Jaccoud, Bichir e Mesquita, 2017).

Despesas com juros e endividamento

Outra despesa de impacto nos gastos federais é o pagamento de juros da dívida pública. Ao longo das últimas décadas, o governo federal reorganizou as regras de endividamento vigentes no país por meio de resoluçóes do Senado, leis ordinárias e, especialmente, com a aprovação da LRF, como apresentado na seção 1 .
O controle do endividamento de estados e municípios pela União implicou a assunção de um modelo de metas fiscais em que o resultado primário positivo permitiria o pagamento de juros e amortização da dívida, inclusive pelos entes que refinanciaram suas dívidas com a União no final dos anos 1990 e início dos anos 2000.

O setor público pagou valores elevados em juros nominais ao longo de todo o período, embora uma tendência de queda seja observada entre os anos 2003 e 2014, com nova elevação a partir de 2015 (8,4\%). Os anos que apresentaram maiores juros nominais foram 1999, com $12,5 \%$, e 2015 , com $8,4 \%$.

Ao longo de quase duas décadas, desde que foi adotada a política de superávits primários, em 1999, o governo federal gerou superávits em todos os exercícios fiscais entre aquele ano e 2013, e déficits entre 2014 e 2016. O comportamento do endividamento, entretanto, não responde apenas ou principalmente à política de geração de superávit pelos três entes da federação. A razão dívida líquida/PIB, relação mais usada como indicador da saúde financeira do setor público, apresentada no gráfico 6 , responde também aos juros pagos anualmente e à taxa de crescimento do PIB.

\section{Gráfico 6 - Dívida Líquida do Setor Público - \% PIB \\ Dívida líquida do setor público - \% PIB}

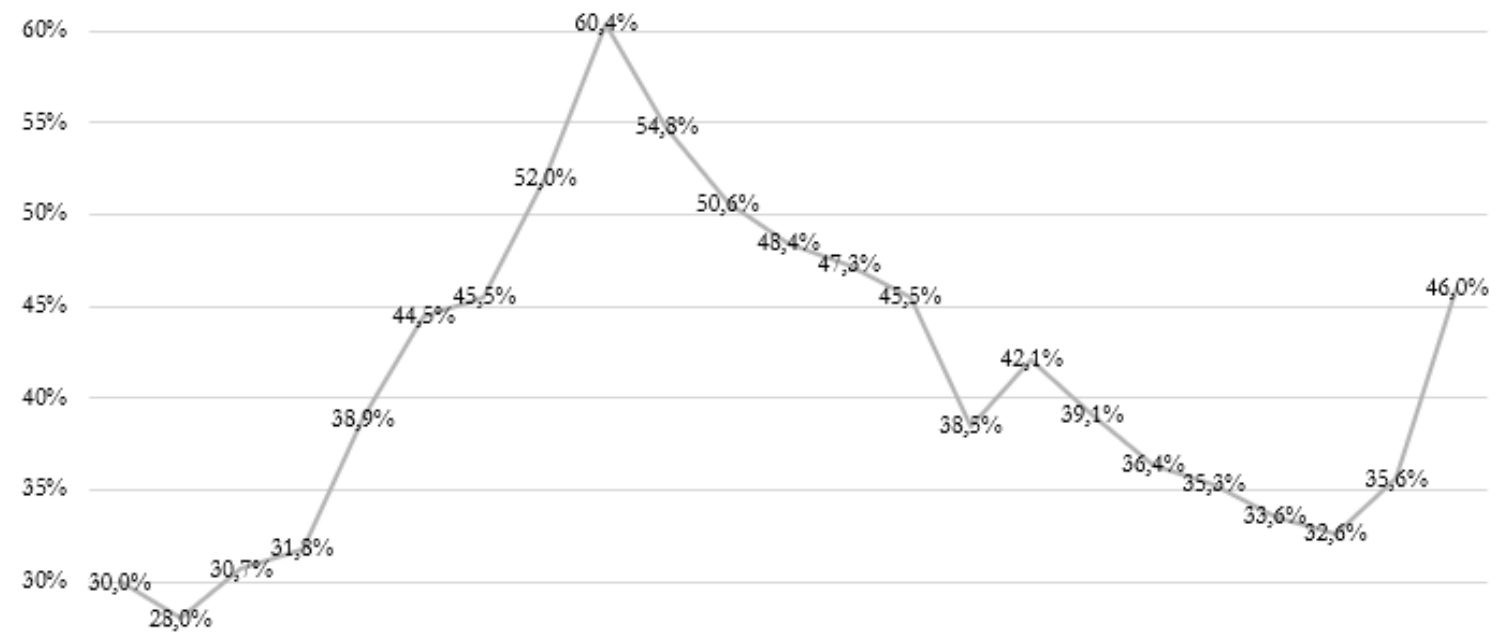

$25 \%$

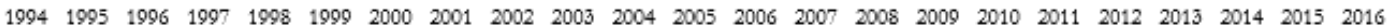

Fonte: Elaboração própria com base em dados do Banco Central do Brasil (BCB) 
Como pode ser observado no gráfico 6, e apesar da elevação da carga tributária, a razão dívida líquida/PIB cresceu em praticamente todo o período que vai do início do Plano Real até 2002, experimentando a partir daí queda sistemática até 2014 e agudo crescimento em 2015/2016. É determinante para a queda ou a elevação da razão dívida líquida/PIB a combinação do resultado primário obtido e do montante de juros pagos anualmente com a taxa de crescimento real do PIB. A combinação de altas taxas de juros e desvalorização cambial com baixo crescimento do PIB entre 1995 e 2002, mesmo com superávits primários elevados entre 1999 e 2002, está na raiz da elevação do endividamento nesse período. No período 2003-2013, a manutenção de superávits primários acima de 3\% do PIB ao ano, a relativa queda dos juros, ao lado de valorização do câmbio e a progressiva redução da vulnerabilidade externa criaram as condições para a diminuição do endividamento líquido do país. A elevação da razão dívida líquida/PIB a partir de 2015 mostra com clareza que a combinação de déficits primários, altas taxas de juros e queda do PIB é explosiva para a sustentabilidade do endividamento público.

Gastos com subsídios ao setor privado

Um elemento importante a provocar aumento das despesas primárias do governo federal nos últimos anos foram os elevados e crescentes subsídios concedidos ao setor privado a partir da crise financeira mundial de 2007/2008. Como pode ser observado no gráfico 7 , o impacto orçamentário desses subsídios se multiplicou por quatro entre 2010 e 2015, após oscilar em patamares relativamente reduzidos entre 1995 e 2010. Chama a atenção a grande expansão dos gastos com subsídios em 2015 e 2016. ${ }^{9}$ Esses gastos deverão se manter em patamar elevado durante os próximos anos, especialmente porque parte importante dos subsídios se concentra em empréstimos de longo prazo concedidos pelo BNDES (especialmente o Programa de Sustentação do Investimento - PSI) e em equalização de juros agrícolas, portanto, continuarão onerando o orçamento.

\section{Gráfico 7 - Subsídios e Subvençóes Pagos pelo Governo Federal (1995-2016)}

Subsídios e subvenções pagos pelo governo federal ( $\mathbf{R} \$$ bilhões de 2016 )

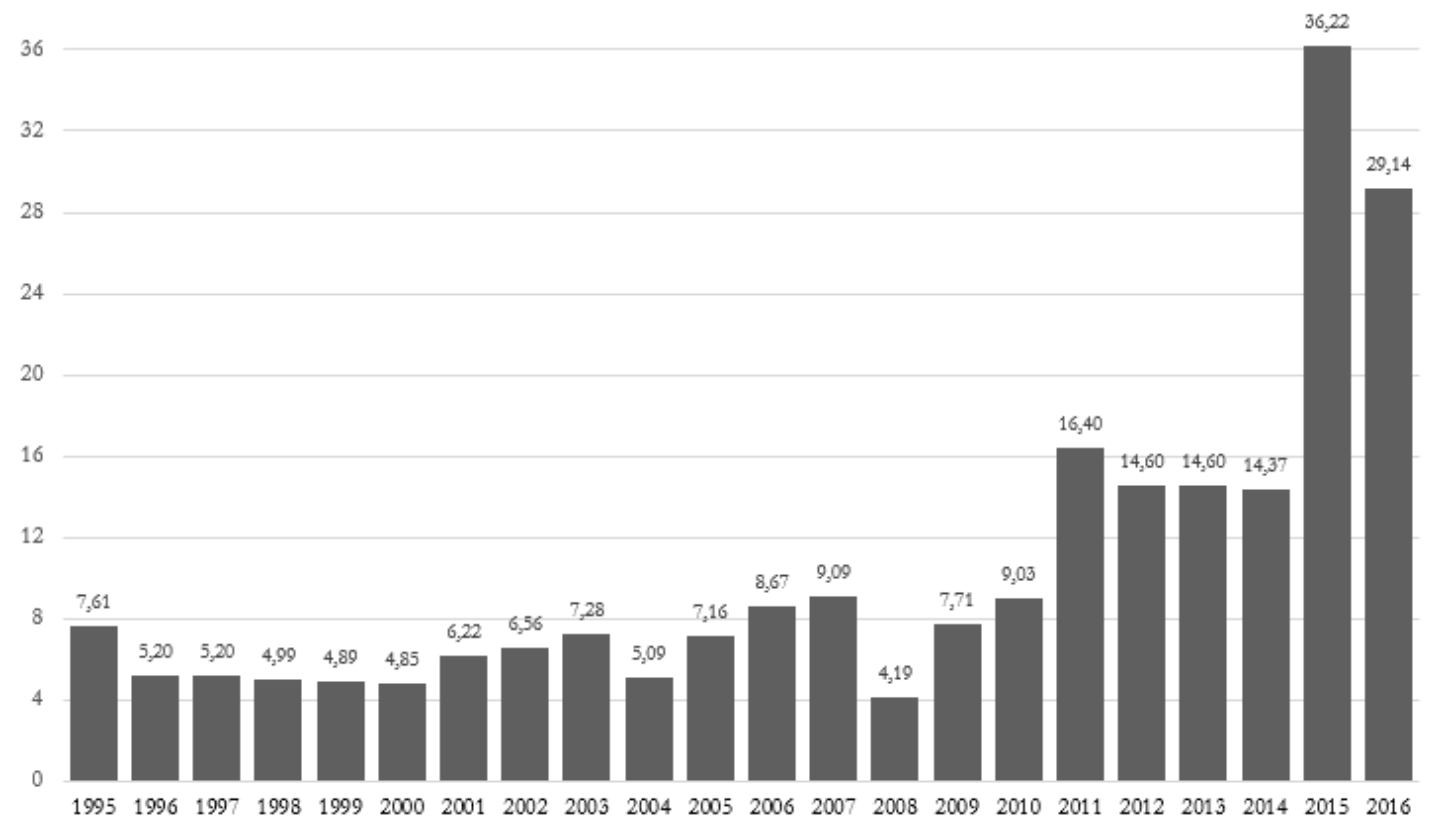

Fonte: Elaboração própria com dados do Ministério do Planejamento. Valores atualizados pelo IPCA 
Rigidez orçamentária e disputa pelo Fundo Público

A estrutura do gasto público federal tem se concentrado nas despesas de seguridade social e educação, além de gastos com juros da dívida e subsídios ao setor privado. A rigidez orçamentária de vinculaçóes de receitas com determinadas despesas, como é o caso dos mínimos constitucionais para educação e saúde, ou a obrigatoriedade legal de gastos, como benefícios sociais, salários, aposentadorias etc., além do pagamento de juros e subsídios têm sido características fundamentais das finanças públicas brasileiras ao longo das últimas décadas. O gráfico 8 permite observar as vinculações da Seguridade Social, que oscilam em torno de $50 \%$; as vinculaçóes do Orçamento Fiscal, por volta de 30\%; e a parte náo vinculada das despesas, de pouco mais de $20 \%$ (Santos, 2016).

Do total da receita do governo federal, apenas cerca de $20 \%$ são recursos discricionários, ou seja, podem ser usados para despesas nas quais é possível fazer escolhas entre diferentes áreas de gasto. Pode-se, inclusive, gastar mais em áreas que possuem recurso vinculado, como a educação, que tem recebido mais do que o mínimo estabelecido pela Constituição, no caso federal. Os recursos para investimentos são, em sua maioria, não vinculados e estaráo entre esses recursos discricionários, assim como o custeio dos ministérios de outras áreas (Habitação, Infraestrutura e Mobilidade Urbana, Desenvolvimento Agrário, Agricultura, Cultura etc.).

Embora as vinculaçóes de recursos tenham produzido efeitos positivos ao assegurarem o financiamento de algumas políticas, outra consequência desse enrijecimento é que as demais políticas passam a disputar uma fraçáo bastante reduzida de recursos, levando a uma crise de financiamento agravada pela queda de arrecadação e pela EC 95/2016 ${ }^{10}$ (Oliveira, 2018, p. 169).

\section{Gráfico 8 - Vinculaçóes de Despesas da Uniáo - 2000/2015 \\ Vinculações de despesas da União 2000-2015}

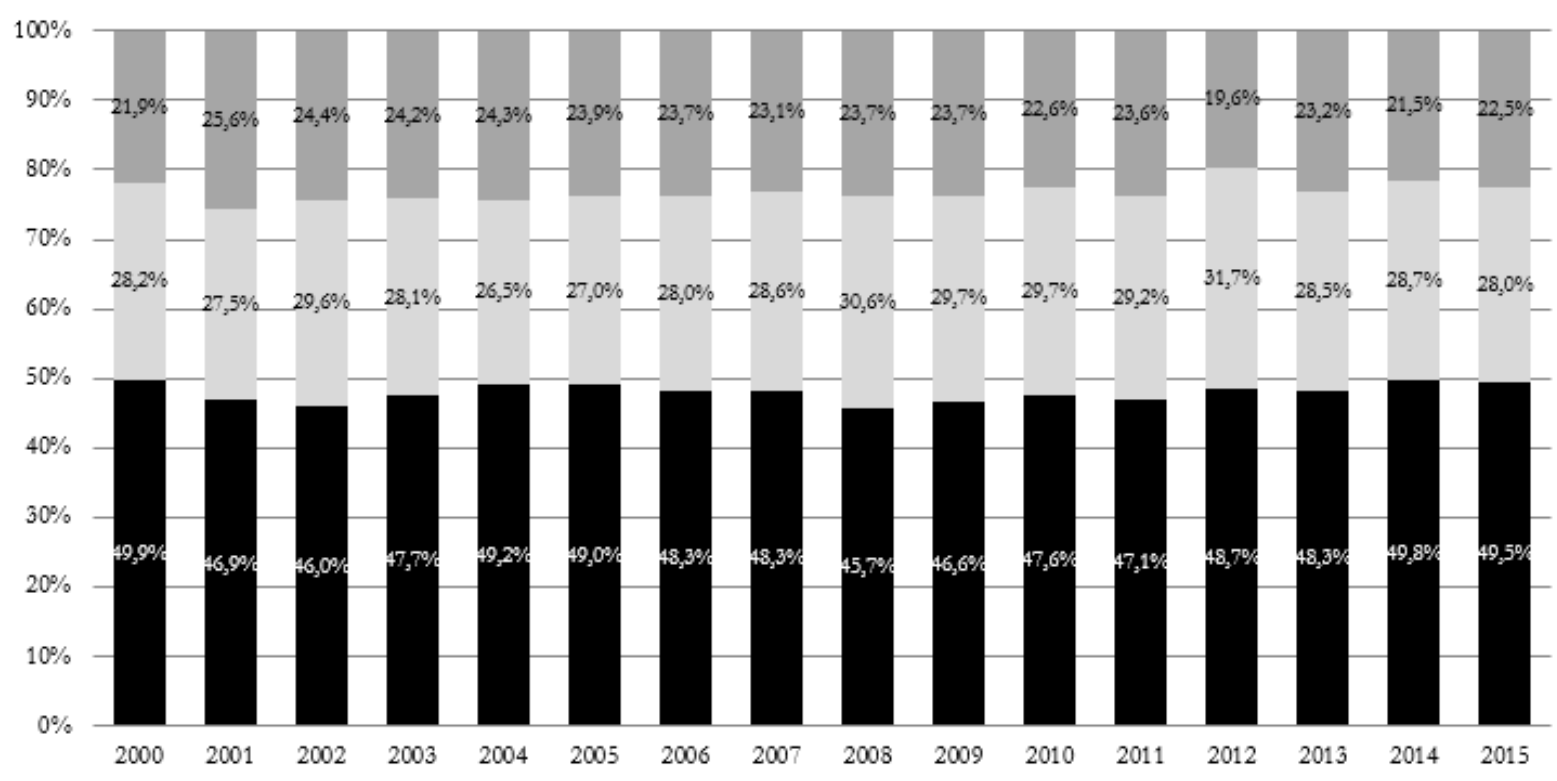

-Vinculações no âmbito da Seguridade Social $\backsim$ Vinculações no âmbito do Orçamento Fiscal $\backsim$ Não Vinculadas

Fonte: Elaboração própria com dados do Ministério do Planejamento 
Tabela 1

Alíquota Efetiva $^{1}$ da Renda, por Faixa de Salários Mínimos Mensais (2007-2016)

\begin{tabular}{|c|c|c|c|c|c|c|c|}
\hline \multirow{2}{*}{$\begin{array}{l}\text { Faixa de renda } \\
\text { mensal/ano }\end{array}$} & \multicolumn{3}{|c|}{ \% Declarantes } & \multicolumn{4}{|c|}{ Alíquota efetiva da renda tributável e isenta } \\
\hline & 2007 & 2013 & 2016 & 2007 & 2013 & 2016 & $\begin{array}{c}\text { Variaçáo } \\
2007 / 2016\end{array}$ \\
\hline Até 20 SM & $91,60 \%$ & $91,60 \%$ & $92,26 \%$ & $3,10 \%$ & $4,10 \%$ & $4,51 \%$ & $1,41 \%$ \\
\hline 20 a 40 SM & $5,50 \%$ & $5,70 \%$ & $5,31 \%$ & $11,70 \%$ & $11,20 \%$ & $10,32 \%$ & $-1,38 \%$ \\
\hline 40 a 80 SM & $2,10 \%$ & $2,00 \%$ & $1,72 \%$ & $12,90 \%$ & $10,10 \%$ & $8,61 \%$ & $-4,29 \%$ \\
\hline 80 a 160 SM & $0,50 \%$ & $0,50 \%$ & $0,46 \%$ & $10,30 \%$ & $6,60 \%$ & $5,68 \%$ & $-4,62 \%$ \\
\hline$>160 \mathrm{SM}$ & $0,30 \%$ & $0,30 \%$ & $0,24 \%$ & $4,40 \%$ & $3,30 \%$ & $2,53 \%$ & $-1,87 \%$ \\
\hline
\end{tabular}

${ }^{1}$ Divisão do imposto pago pela soma das rendas tributável e isenta. A Receita Federal passou a divulgar os rendimentos declarados por faixa de salário mínimo a partir do ano calendário de 2007.

Fonte: Elaboração própria com dados da Receita Federal do Brasil. 2016 (Grandes números do IRPF); 2007-2013 citados em Relatório da distribuição pessoal da renda e da riqueza da população brasileira. SPE/MF, maio de 2016

Gastos com pessoal

Os gastos de pessoal ativo e inativo da União, apesar de frequentemente apresentados como componente explosivo da elevaçáo da despesa pública no Brasil, vêm apresentando tendência decrescente como proporção do PIB ao longo das últimas duas décadas, exceto em anos de estagnação ou decréscimo do produto, como é o caso do ano de 2009 e de 2014 a 2016. Depois de atingir um pico de 4,9\% do PIB em 2002, as despesas totais com pessoal mostram clara tendência de queda nos anos seguintes, chegando a $4,1 \%$ do PIB em 2016 e a um valor médio no período de 4,3\% do PIB. Os gastos com inativos caíram 0,56\% do PIB entre o pico do ano de 2001 e 2016, enquanto os gastos com pessoal ativo se reduziram em 0,23\% do PIB entre 2002 e 2016.

Esse comportamento das despesas de pessoal ocorreu mesmo com elevações expressivas da força de trabalho em áreas finalísticas como Educação e Defesa Nacional. A redução de despesas de pessoal ocorreu sistematicamente em quase todos os anos com crescimento real do PIB, mostrando que a rigidez da alocação orçamentária para pessoal na União é muito menor do que se difunde e do que supóe o senso comum.

A análise dessa dimensão ilumina a contradição entre o aumento da disputa democrática pelo fundo público após a Constituição e o enrijecimento dos espaços orçamentários a partir da vinculação das receitas do governo e da obrigatoriedade legal de parcelas crescentes das despesas. A disputa por espaço orçamentário é bastante dificultada pela pressão exercida pela despesa com juros da dívida sobre o crescente endividamento público.

\section{Consideraçóes finais}

A questão do endividamento está no centro da mudança radical do regime fiscal que decorre da Emenda Constitucional 95/2016 (PEC 241/55). ${ }^{11}$ A recessão, a contínua elevação dos gastos obrigatórios, dos subsídios ao setor privado e do pagamento de juros da dívida levaram a uma situação de crise fiscal, intensificada pela crise política. O chamado "novo regime fiscal" tem como objetivo central a diminuição do tamanho do Estado e a redução do escopo de suas políticas.

A existência de um teto constitucional para as despesas primárias por 20 anos vai reduzir as despesas públicas como proporção do PIB e o valor per capita para todas as áreas de políticas públicas, mesmo aquelas protegidas por vinculaçóes constitucionais de parcelas das receitas de impostos, que foram suspensas e tiveram seu valor real congelado pelo período. Dada ainda a previsível continuidade da elevação real de gastos previdenciários, as despesas não protegidas por vinculaçóes terão que ser reduzidas em seu valor real. Áreas de políticas urbanas como habitação, 
saneamento, transporte coletivo e infraestrutura urbana serão certamente alvo dessa reduçáo, ao lado de políticas já historicamente com reduzido espaço orçamentário, como cultura, ciência e tecnologia e desenvolvimento agrário.

A trajetória do orçamento público brasileiro no período recente (desde o governo FHC), assim como os desafios colocados pela aprovação da EC 95/2016 podem ser mais bem sintetizados retomando-se as quatro dimensões, contraditórias e paradoxais, em torno das quais desenvolvemos a análise até aqui.

1. Centralização versus descentralizaçáo dos recursos públicos - $\mathrm{O}$ processo de centralização versus descentralização, que tem implicaçóes importantes nas receitas e nas despesas para as áreas de educação, saúde e assistência social, não foi linear e homogêneo entre as políticas e nem entre governos. Na mudança para os governos do PT, a educação ganhou mais espaço no orçamento da União, e a criaçáo do Fundeb ampliou as transferências federais para os entes subnacionais. Na Assistência Social, a ampliação orçamentária teve a estruturação do Bolsa Família como elemento fundamental, além da ampliação do BPC e a estruturação programática do SUAS. Apesar do aumento de transferências para os entes subnacionais, o gasto total da União em saúde se manteve em patamar abaixo do recomendado pela regulamentação da Emenda 29/00, e a responsabilidade orçamentária dos municípios foi bastante ampliada.

No que diz respeito ao novo regime fiscal criado pela aprovação da EC nº 95/2016, a maior participação dos municípios na receita disponível tende a ser mantida e ampliada. Na estrutura das receitas, a opção por contribuiçóes que permitiram recentralizar recursos após a CF 88 deve permanecer, e também o controle do endividamento de estados e municípios e as regras para despesa de pessoal. A descentralização de competências, que fica mais evidente nas áreas de saúde e educação, deve ser mantida e aprofundada com a expressiva redução das despesas primárias federais como proporção do PIB.

2. Transparência e accountability versus complexidade orçamentária - A estrutura formal do orçamento brasileiro tem ampliado a possibilidade de acesso às informaçôes orçamentárias e financeiras. No entanto, esta é uma discussão que avançou pouco na sociedade em função da complexidade das normas, que tornam difícil a compreensão de como são alocados os recursos públicos no país. Apesar da maior participação setorial no orçamento, em especial nos dois governos Lula, não é possível afirmar que as mudanças de regras e controles em prol da maior transparência orçamentária tenham garantido maior envolvimento da população na discussão da receita e do gasto público.

3. Disputa democrática pelo fundo público versus vinculaçóes - Já na disputa democrática pelo fundo público versus vinculações orçamentárias, a análise dos dados mostrou uma concentraçáo alocativa de recursos voltados a algumas áreas sociais, sobretudo previdência social, assistência social, saúde e educação, e ao pagamento de juros da dívida. O crescimento das despesas obrigatórias tem sido uma tendência desde os governos FHC, mantida e incrementada pelos demais governos. A partir de 2011, com o fim da DRU para a área de educação, houve expressivo aumento de recursos para o financiamento dessa política.

Parte dessa decisão alocativa está dada por regras de proteção da despesa, enfraquecidas ou eliminadas pela EC 95/2016. Por outro lado, a drástica redução das despesas primárias federais no novo regime fiscal vai acirrar a disputa pelo financiamento entre as políticas. O espaço das despesas não obrigatórias é restrito e tende a diminuir nos próximos anos com a imposição do teto de despesas e a continuidade do aumento das despesas previdenciárias. É relevante ressaltar novamente que a vinculaçáo de recursos garantiu o crescimento e o fortalecimento das áreas sociais, como apresentado no texto, porém trouxe desafios para o financiamento das demais políticas, pois dificulta o atendimento de demandas náo protegidas por vinculações.

4. Reduçáo das desigualdades versus concentraçáo de renda - Por fim, a contradição entre diminuição da pobreza e concentração de renda não foi enfrentada em nenhum dos governos do período 1995-2016, e uma reforma tributária ampla e progressiva que contribuísse para reduzir a concentração de renda no país não chegou a ser priorizada. Os dados mostram a manutenção de um padrão concentrador na política tributária das últimas décadas, sendo possível identificar um agravamento da estrutura regressiva da tributação durante os governos de Fernando Henrique Cardoso. 
Esse padrão é fortalecido por uma política de juros nominais elevados e de alocação de recursos em subsídios ao setor privado.

Apesar disso, observa-se no período uma tendência importante de redução da desigualdade social decorrente da alocação do gasto público em diferentes políticas a partir de meados dos anos 1990. Neste caso, é importante ressaltar os aumentos reais do salário mínimo, que precedem o governo Lula, mas foram ampliados com a regra de atualização pela variação real do PIB, permitindo ganhos importantes no RGPS, nos benefícios da assistência social e no mercado de trabalho. A trajetória de aumento dos gastos públicos em educação e saúde ampliou o acesso a esses serviços, incidindo sobre uma dimensão não monetária da desigualdade. No nosso entender, os dados mostram, corroborando a conclusão de Arretche (2018, p. 18), que a diferenciação partidária (programático-ideológica) não foi um fator suficiente para explicar a reduçáo da desigualdade ocorrida no período 1995-2016, embora possa determinar diferenças de intensidade observadas no período.

Finalmente, o chamado "novo regime fiscal", criado pela Emenda Constitucional 95/2016, não revê a atual estrutura tributária e vai interromper a tendência redistributiva do gasto público que favorece os mais pobres, agravando, caso não seja revisto, as desigualdades e a concentração de renda.

\section{Notas}

1 O orçamento-programa está associado a um sistema de planejamento organizado por objetivos buscados em programas. É mais complexo que o orçamento de desempenho, pautado pelo objeto do gasto e um plano de trabalho (Core, 2001).

2 Este ponto demonstra a importância política dos instrumentos contábeis no processo orçamentário (Lascoumes; Le Galès, 2012).

3 Para uma discussão dos impactos do Bolsa Família e do Benefício de Prestação Continuada na distribuição de renda, ver Morgan (2017), especialmente página 19 e figura A.5.

4 O salário mínimo teve ganhos reais de 42\% entre 1994 e 2002 , de $62,8 \%$ entre 2002 e 2010 e de $15,5 \%$ entre 2010 e 2016, medidos pelo IPCA.
5 Medeiros e Souza (2013) mostraram os diferentes impactos do RGPS e dos regimes próprios dos servidores públicos estatutários e militares na distribuição de renda. Caetano (2008) apontou o impacto positivo do RGPS na redistribuição regional da renda dos municípios mais ricos para os mais pobres.

6 A vinculação constitucional à Receita Corrente Líquida foi suspensa pela Emenda Constitucional no 95/2016, que determinou a correção dos valores mínimos aplicados pela União, nos 20 anos seguintes, pelo IPCA.

7 A Vinculação da União foi suspensa pela EC 95/2016.

8 O total executado na função assistência pelas capitais brasileiras com recursos da fonte federal foi inferior a 15\% em 2016, conforme dados do Siconfi.

9 Aqui, entretanto, é necessário enfatizar que a análise se restringe aos dados orçamentários, não considerando as diferenças contábeis que tornaram essa conta "errática" no período (Gobetti e Almeida, 2016, p. 29).

10 A EC95/2016, conhecida como a Emenda do Teto, determinou que até 2036 as despesas primárias federais fiquem limitadas aos valores de 2016, sendo apenas corrigidas anualmente pela inflação. O total das despesas, assim como os mínimos constitucionais com educação e saúde ficaráo congelados em seu valor real por todo o período, o que implicará redução como proporção do PIB e em valores per capita (Peres e Santos, 2016).

11 Para uma apresentação mais detalhada sobre a PEC241/55, ver Peres e Santos (2016).

\section{BIBLIOGRAFIA}

AFONSO, José Roberto R.; LUKIC, Melina Rocha \& CASTRO, Kleber Pacheco de. (2018), "ICMS: crise federativa e obsolescência". Rev. direito $G V$, São Paulo, 14, 3: 986-1018, set. 2018.

AFONSO, José Roberto. (2016), "Orçamento Público no Brasil: História e Premência de Reforma". Joaçaba, 17, 1: 9-28, jan./abr.

AFONSO, José Roberto. (2017), "Cenário Fiscal Atual no Brasil: implicaçōes para governos subnacionais". Apresentação realizada no Banco Interamericano de Desarrollo, Washington D.C., 10/10/2017.

ALMEIDA, Maria Hermínia Tavares de. (2005), "Recentralizando a federação?". Revista de Sociologia e Politica, 24: 29-40. 
ARESTIS, Philip; PAULA, Luiz Fernando de \& FERRARI FILHO, Fernando. (2009), “A nova política monetária: uma análise do regime de metas de inflação no Brasil”. Economia e sociedade, 18, 1: 1-30.

ARRETCHE, Marta. (2005), "Quem taxa e quem gasta: a barganha federativa na federação brasileira”. Rev. Sociol. Polit., Curitiba, 24: 69-85, jun.

ARRETCHE, Marta. (2009), "Continuidades e descontinuidades da federaçáo brasileira: de como 1988 facilitou 1995”. Dados, 52, 2: 377-423.

ARRETCHE, Marta. (2018), "Democracia e redução da desigualdade econômica no Brasil: a inclusão dos outsiders". Revista Brasileira de Ciências Sociais, 33, 96: e339613.

BARROS, Ricardo Paes de et al. (2006), “Uma análise das principais causas da queda recente na desigualdade de renda brasileira”. Econômica: revista do programa de pós-graduação em economia da UFF, 8, 1: 117-147.

BARROS, Ricardo Paes de; HENRIQUES, Ricardo \& MENDONÇA, Rosane. (2000), "Desigualdade e Pobreza no Brasil: retrato de uma estabilidade inaceitável". Revista Brasileira de Ciências Sociais, 15, 42: 123-42.

BATISTA JR, Paulo Nogueira. (2002), "Vulnerabilidade externa da economia brasileira”. Estudos avançados, 16, 45: 173-185.

BRASIL. (1996), Lei 9.424, de 24/12/1996: Dispóe sobre o Fundo de Manutenção e Desenvolvimento do Ensino Fundamental e de Valorização do Magistério, na forma prevista no art. $60, \$ 7^{\circ}$, do Ato das Disposiçóes Constitucionais Transitórias, e dá outras providências.

BRASIL. (2014), Instituto Nacional de Estudos e Pesquisas Educacionais Anísio Teixeira. Ofício no 024/2014 - GM/MEC. Resposta ao Ofício no 204 (SF), de 17 de fevereiro de 2014, que versa sobre o Requerimento de Informação ${ }^{\circ}$ 1173/2013, de autoria do Senador Randolfe Rodrigues. Disponível em https://bit.ly/2EpAYrH, consultado em 16/09/2018.

BRASIL. (2019), IBGE - "IBGE Conta Satélite da Saúde". Disponível em https://www.ibge.gov. br/estatisticas/sociais/saude/9056-conta-satelite- de-saude.html? =\&t= downloads, consultado em 04/07/2019.

BRASIL. (2011), Conselho Nacional de Secretários de Saúde. O Financiamento da Saúde. 1a edição, Brasília, Conass.

BRASIL, Finbra (2016), "Despesa Orçamentária das Capitais". Disponível em https://bit.ly/2IYUhqp, consultado em 31/08/2018.

BRASIL, Haroldo Guimarães. (1993), "Processo decisório e a questão orçamentária: uma analogia". Revista de Administraçâo Pública, 27, 3: 115-146.

BRASIL. (2015), Secretaria de Articulação com os Sistemas de Ensino/Ministério da Educação. "Instituir um Sistema Nacional de Educação: agenda obrigatória para o país". Disponível em https://bit.ly/2y2yVqh, consultado em 10/06/2016.

BRASIL. (2016), Secretaria de Política Econômica (SPE/MF). "Relatório da Distribuição Pessoal da Renda e da Riqueza da População Brasileira (Dados do IRPF 2015/2014)". Disponível em https:// bit.ly/2IJCJAN, consultado em 03/09/2018.

BRITO, Alessandra Scalioni. (2015), O papel do salário mínimo na redução da desigualdade na distribuição de renda no Brasil entre 1995 e 2013. Tese de Doutorado em Ciências Econômicas, Universidade Federal Fluminense, Niterói.

CAETANO, Marcelo Abi-Ramia. (2008), "Previdência social como instrumento de distribuição regional da renda”. Texto para discussão-Boletim Regional, Urbano e Ambiental, p. 23 - 26. Rio de Janeiro, Ipea.

CALLEGARI, Cesar. (2010), O FUNDEB e o Financiamento da educação pública no estado de São Paulo. 5 a edição, São Paulo, Aquariana.

CALLEGARI, César. (2013), "O Financiamento da Educação Básica”, in: ABMP \& Todos Pela Educação (org.), Justiça pela Qualidade na Educação, p. 223-265, São Paulo, Editora Saraiva.

CASTRO, Jorge Abrahão de et al. (2012), "Gasto Social Federal: prioridade macroeconômica no período 1995-2010". Nota Técnica n 9. Brasília, Ipea.

CASTRO, Jorge Abrahão de. (2011), "Financiamento da educação pública no Brasil: evolução dos gastos", in A. B. Gouveia; J. M. R. Pinto \& P. R. Corbucci, Federalismo e politicas educacionais 
na efetivação do direito à educação no Brasil, p. 29-49, Brasília, IPEA.

CASTRO, Jorge Abrahão de; BARRETO, Angela Rabelo \& CORBUCCI, Paulo Roberto. (2000), "A reestruturação das políticas federais para o ensino fundamental: descentralização e novos mecanismos de gestão". Texto para discussáo no 745, Rio de Janeiro, Ipea.

CORE, Fabiano Garcia. (2001), "Reforma gerencial dos processos de planejamento e orçamento". Texto para a Discussáo no 44, Brasília, Enap.

FAGNANI, Eduardo. (2019), "Justiça fiscal é possível: subsídios para o debate democrático sobre o novo desenho da tributação brasileira". A Reforma Tributária Necessária, p. 19-41.

FANDIÑO, Pedro \& KERSTENETZKY, Celia Lessa. (2019), "O paradoxo constitucional brasileiro: direitos sociais sob tributação regressiva”. Brazilian Journal of Political Economy, 39, 2: 306-327.

FARENZENA, Nalú. (2006), A Politica de Financiamento da Educação Básica: rumos na legislação brasileira. Porto Alegre, UFRGS Editora.

FAVERET, Ana Cecília de Sá Campello. (2003), "A vinculação constitucional de recursos para a saúde: avanços, entraves e perspectivas". Ciência \& Saúde Coletiva, 8: 371-378.

FERNANDES, Rodrigo Cardoso; CAMPOLINA Bernardo \& SILVEIRA, Fernando Gaiger. (2019), "Imposto de Renda e Distribuição de Renda no Brasil”. Texto para discussáo, Instituto de Pesquisa Econômica Aplicada. Brasília, Rio de Janeiro, Ipea.

GOBETTI, Sérgio Wulff \& ALMEIDA, Vinícius Lima de. (2016), "Uma radiografia do gasto público federal entre 2001 e 2015”. Texto para Discussão, Instituto de Pesquisa Econômica Aplicada. Brasília, Rio de Janeiro, Ipea.

GOBETTI, Sérgio Wulff \& ORAIR, Rodrigo Octávio. (2016), "Progressividade tributária: a agenda negligenciada". Texto para Discussão $n^{o}$ 2190. Rio de Janeiro, Ipea.

GOMES, Emerson Cesar da Silva. (2013), "O Financiamento da Educação Básica no Brasil”, in ABMP \& Todos Pela Educação. Justiça pela
Qualidade na Educação, p. 266-287. São Paulo, Editora Saraiva.

GRANADO, Antonio \& PERES, Ursula Dias. (2010), "Reforma tributária: Aspectos importantes acerca da Federação, atribuiçôes dos entes e o financiamento da ação pública". Cadernos Adenauer, 1: 45-61.

GUARDIA, Eduardo Refinetti et al. (1993), Orçamento Público e Politica Fiscal: aspectos institucionais e a experiência recente-1985/1991. Dissertação de Mestrado, Universidade Estadual de Campinas.

HELFAND, Steven; ROCHA, Rudi \& VINHAIS, Henrique. (2009), "Pobreza e desigualdade de renda no Brasil rural: uma análise da queda recente". Pesquisa e Planejamento Econômico (PPE), 39, 1: 59-80.

JACCOUD, Luciana \& VIEIRA, Fabiola Sulpino. (2018), "Federalismo, Integralidade e Autonomia no SUS: Desvinculação da Aplicação de Recursos Federais e os Desafios da Coordenação". Texto para discussão, Instituto de Pesquisa Econômica Aplicada. Brasília, Rio de Janeiro, Ipea

JACCOUD, Luciana; BICHIR, Renata \& MESQUITA, Ana Cleusa. (2017), "O SUAS na Proteção Social Brasileira: Transformaçôes recentes e perspectivas”. Novos estudos Cebrap, 36, 2: 37-53, out.

LASCOUMES, Pierre \& LE GALÈS, Patrick. (2012), "A ação pública abordada pelos seus instrumentos". Revista Pós Ciências Sociais, 9, 18: 19-44.

LAZZARI, Eduardo Alves \& LEAL, Jefferson Lécio. (2017), "A evolução e a política tributária do irpf”. $41^{\circ}$ Encontro Anual da ANPOCS.

LEVI, Maria Luiza. (2016), "Sistema de Saúde no Brasil: redistributividade no modelo de financiamento e provisão". Rev. Parlamento e Sociedade, 4, 7: 33-63.

LIMONTI, Rogério Machado; PERES, Ursula Dias \& CALDAS, Eduardo de Lima. (2014), "Política de fundos na educação e desigualdades municipais no estado de São Paulo: uma análise a partir das arenas políticas de Lowi”. Revista de Administraçâo Pública, 48, 2: 389-410.

MARTINS, Paulo de Sena. (2010), "O financiamento da educação básica como política pública”. 
Revista Brasileira de Política e Administração da Educação, 23, 3: 497-514.

MEDEIROS, Marcelo \& SOUZA, Pedro H. G. F. (2014), "Previdências dos trabalhadores dos setores público e privado e desigualdade no Brasil”. Economia Aplicada, 18, 4, 603-623.

MEDEIROS, Marcelo \& SOUZA, Pedro. (2013), "Gasto público, tributos e desigualdade de renda no Brasil”. Texto para discussão no 1844 . Rio de Janeiro, Ipea.

MENDES, Aquila \& FUNCIA, Francisco Rózs. (2016) "O SUS e seu financiamento", in R. M. Marques; S. F. Piola \& A. Carrillo Roa, Sistema de saúde no Brasil: organização e financiamento. Rio de Janeiro, Ministério da Saúde.

MORGAN, Marc. (2017), "Falling Inequality beneath Extreme and Persistent Concentration: New Evidence for Brazil Combining National Accounts, Surveys and Fiscal Data, 2001-2015”. Working Paper Series, 12.

PEDERIVA, João Henrique. (2016), “Transparência orçamentária e responsividade democrática na Espanha e no Brasil”, in Valdemir Pires, André Rehbein Sathler (orgs.), Gestão orçamentária inovadora: desafios e perspectivas no Brasil. Brasília, Senado Federal, Coordenação de Edições Técnicas.

OLIVEIRA, Fabrício Augusto de. (2018), "O orçamento como instrumento da democracia e da cidadania: a importância das vinculaçôes". A Reforma Tributária Necessária, p. 163-172.

PERES, Ursula Dias. (2007), Arranjo institucional do financiamento do ensino fundamental no Brasil: consideraçóes sobre os municípios brasileiros e estudo de caso do município de Sáo Paulo no periodo de 1997 a 2006. Tese de Doutorado, Fundação Getúlio Vargas, São Paulo.

PERES, Ursula Dias. (1999), A influência da inflação no processo orçamentário brasileiro. Estudo de caso: execução orçamentária do estado de São Paulo de 1991 a 1997. Dissertação de Mestrado, Fundação Getúlio Vargas, São Paulo.

PERES, Ursula Dias \& MATTOS, Bruna Barcellos. (2017), "A participação social e o conflito distributivo na planificação e orçamentação públicas: o caso do município de São Paulo”. Cadernos Gestão Pública e Cidadania, 22, 73: 456-477.
PERES, Ursula Dias \& SANTOS, Fabio Pereira dos. (2016), "PEC 241/55: Redução do Estado, Aumento da Desigualdade". Revista do Conselho Federal de Economia, 7, 22: 17-26.

PIERSON, Paul. (1993), "When Effect Becomes Cause: Policy Feedback and Political Change". World Politics, 45, 4: 595-628.

PIOLA, Sergio Francisco; BENEVIDES, Rodrigo Pucci de Sá \& VIEIRA, Fabiola Sulpino. (2018), "Consolidação do Gasto com Açôes e Serviços Públicos em Saúde: trajetória e percalços no período de 2003 a 2017”. Texto para discussão, Instituto de Pesquisa Econômica Aplicada. Brasília, Rio de Janeiro, Ipea.

PISCITELLI, Roberto. (1988), “O processo de elaboração e execução orçamentária no Brasil: algumas de suas peculiaridades". Revista de Economia Política, 8, 3: 88-100.

REZENDE PINTO, José Marcelino. (2002), "Financiamento da educação no Brasil: um balanço do Governo FHC (1995-2002)". Educação e Sociedade, 23, 80: 108-135.

REZENDE PINTO, José Marcelino \& ADRIĀO, Theresa. (2006), "Noçóes gerais sobre o financiamento da educação no Brasil". EccoS Revista Científica, 8, 1: 23-46.

RODRIGUEZ, Vicente. (2001), "Financiamento da educação e políticas públicas: o Fundef e a política de descentralização". Cadernos Cedes, 21, 55: 42-57.

SANTOS, Fabio Pereira dos. (2000), O Plano Real e o crescimento da divida pública no Brasil. Dissertação de Mestrado, Fundação Getúlio Vargas, São Paulo.

SANTOS, Fabio Pereira dos. (2016), "Notas sobre o financiamento das políticas públicas no Brasil e na cidade de São Paulo". Rev. Parlamento e Sociedade, 4, 7: 15-32.

SEGATTO, Catarina Ianni \& ABRUCIO, Fernando Luiz. (2016), "A cooperação em uma federação heterogênea: o regime de colaboração na educação em seis estados brasileiros". Rev. Bras. Educ., Rio de Janeiro, 21, 65: 411-429, jun.

SILVA, Maria Ozanira da Silva. (2007), "O Bolsa Família: problematizando questôes centrais na 
política de transferência de renda no Brasil”. Ciência \& Saúde Coletiva, 12: 1429-1439.

SILVEIRA, Fernando Gaiger. (2012). Equidade Fiscal: impactos distributivos da tributação e do gasto social. Monografia apresentada ao XVII Prêmio Tesouro Nacional - 2012.

SKOCPOL, Theda. (1992), Protecting Soldiers and Mothers. Cambridge, MA, Harvard University Press.

VAITSMAN, Jeni; ANDRADE, Gabriela Rieveres Borges de \& FARIAS, Luis Otávio. (2009),
"Proteção social no Brasil: o que mudou na assistência social após a Constituição de 1988”. Ciência \& Saúde Coletiva, 14, 3: 731-741.

VIANA, Ana Luiza D'Ávila \& MACHADO, Cristiani Vieira. (2008), "Proteção social em saúde: um balanço dos 20 anos do SUS”. Physis: Revista de Saúde Coletiva, 18: 645-684.

WILDAVSKY, Aaron. (1969), "Rescuing Policy Analysis from PPBS". Public Administration Review, 29, 2: 189-202. 


\section{GASTO PÚBLICO E DESIGUALDADE SOCIAL $O$ ORÇAMENTO DO GOVERNO FEDERAL BRASILEIRO ENTRE 1995 E 2016}

\author{
Ursula Dias Peres e Fábio Pereira dos \\ Santos
}

Palavras-chave: Orçamento público; Desigualdade social; Governo federal; Conflito distributivo.

Este artigo busca mostrar que nas últimas décadas a política orçamentária do governo federal brasileiro permitiu tanto a ampliaçáo de gastos sociais e a redução da desigualdade como a concentraçáo de renda no Brasil. O texto analisa dados orçamentários federais de receitas e despesas para o período de 1995 a 2016. Argumenta que a trajetória do orçamento público brasileiro no regime democrático contemporâneo foi afetada por quatro diferentes dimensóes que operaram contraditoriamente. A primeira diz respeito à centralização versus descentralização dos recursos públicos. A segunda é dada pelo acirramento da disputa pelo fundo público versus a vinculaçáo constitucional/legal de recursos. A terceira envolve a ampliação de transparência e accountability sobre os orçamentos, que operaram contraditoriamente com a crescente complexificaçáo das contas públicas. Por fim, a ampliação do gasto social conviveu com a regressividade da arrecadação tributária.

\section{PUBLIC EXPENDITURE AND SOCIAL INEQUALITY: THE BRAZILIAN FEDERAL GOVERNMENT BUDGET BETWEEN 1995 AND 2016}

\author{
Ursula Dias Peres and Fábio Pereira dos \\ Santos
}

Keywords: Public budget; Social inequality; Central government; Distributive conflict.

This paper aims to show that over the last decades, the Brazilian federal government's budget policy has allowed both the expansion of social spending and the reduction of inequality, as well as the concentration of income in Brazil. The article analyzes the budget expenditures arguing that the trajectory of the Brazilian public budget in the contemporary democratic regime was affected by four different dimensions that operated contradictorily. The first of these dimensions concerns the centralization versus decentralization of public resources. The second dimension is the permanent dispute over the public fund versus the constitutional earmarking. Actions of greater transparency and accountability on budgets have operated in contradiction with the growing complexity of public accounts. Finally, the expansion of social spending - which produced a reduction of social inequalities - grew in tandem with the regressivity of the tax collection.

\section{DEPENSES PUBLIQUES ET \\ INEGALITE SOCIALE: LE BUDGET DU GOUVERNEMENT FEDERAL BRESILIEN ENTRE 1995 ET 2016}

\author{
Ursula Dias Peres et Fábio Pereira dos \\ Santos
}

Mots-clés: Budget public; Inégalité sociale; Gouvernement fédéral; Conflit distributif.

Cet article vise à montrer qu'au cours des dernières décennies, la politique budgétaire du gouvernement fédéral brésilien a autant permis l'augmentation des dépenses sociales et la réduction de l'inégalité que la concentration du revenu dans le pays. Le texte analyse des données budgétaires fédérales de recettes et dépenses pour la période allant de 1995 à 2016 . L'objectif est de montrer que le budget public brésilien sous le régime démocratique contemporain a été affecté par quatre dimensions différentes et contradictoires: centralisation versus décentralisation des ressources publiques; une plus grande dispute pour les fonds publics versus le lien constitutionnel/légal de ressources ; augmentation de la transparence et accountability sur les budgets, qui ont opéré différemment avec la complexification croissante des comptes publics ; enfin, l'augmentation des dépenses sociales en même temps que la dégressivité des prélèvements fiscaux. 


\section{Anexo I - Lista de Siglas}

BNDES - Banco Nacional de Desenvolvimento Econômico e Social

BPC - Benefício de Prestação Continuada

CEF - Caixa Econômica Federal

$\mathrm{CF}$ - Constituição Federal

COFINS - Contribuição para o Financiamento da Seguridade Social

CSLL - Coontribuição Social sobre o Lucro Líquido

DRU - Desvinculação de Receitas da União

EC - Emenda Constitucional

FHC - Fernando Henrique Cardoso

FPE - Fundo de Participação dos Estados

FPM - Fundo de Participação dos Municípios

FUNDEB - Fundo de Manutenção e Desenvolvimento da Educação Básica e de Valorização dos Profissionais da Educação

FUNDEF - Fundo de Manutenção e Desenvolvimento do Ensino Fundamental e de Valorização do Magistério

IBGE - Instituto Brasileiro de Geografia e Estatística

ICMS - Imposto sobre Circulação de Mercadorias e Serviços

INEP - Instituto Nacional de Estudos e Pesquisas Educacionais Anísio Teixeira

IPCA - Índice Nacional de Preços ao Consumidor Amplo

IPI - Imposto sobre Produtos Industrializados

IRPF - Imposto de Renda Pessoa Física

LDO - Lei de Diretrizes Orçamentárias

LOA - Lei Orçamentária Anual

LRF - Lei de Responsabilidade Fiscal

MDE - Manutenção e Desenvolvimento do Ensino

PAC - Programa de Aceleração do Crescimento

PEC - Proposta de Emenda Constitucional

PIB - Produto Interno Bruto

PIS - Programa de Integração Social

PNAD - Pesquisa Nacional por Amostra de Domicílios

PNAS - Política Nacional de Assitência Social

POF - Pesquisa de Orçamentos Familiares

PPA - Plano Plurianual

PSI - Programa de Sustentação do Investimento

PT - Partido dos Trabalhadores

RCL - Receita Corrente Líquida

RFB - Receita Federal do Brasil

RGPS - Regime Geral de Previdência Social

RMV - Renda Mensal Vitalícia

RPPS - Regime Próprio de Previdência Social

SUAS - Sistema Único da Assistência Social

STN - Secretaria do Tesouro Nacional 